\title{
The Influence of Competence User Information System on User Satisfaction New Student Admission Information System in University of Swadaya Gunung Jati
}

\author{
Danang Nuswantoro \\ Magister Students of Management Department Faculty of \\ Post Graduate, \\ Universitas Komputer Indonesia, \\ Bandung, Indonesia \\ danang.pusdat@gmail.com
}

\author{
Deden Abdul Wahab Syahroni \\ Lecturer of Management Department Faculty of \\ Post Graduate, \\ Universitas Komputer Indonesia, \\ Bandung, Indonesia \\ wahab_dens@yahoo.com
}

\begin{abstract}
Swadaya Gunung Jati University (Unswagati) as the oldest and largest university in the CIAYUMAJAKUNING area (Cirebon, Indramayu, Majalengka, Kuningan) in recent years has experienced a decline in new student admissions. As one of the steps to anticipate, Unswagati applies online-based new student admissions as the new student admission information system (SIMABAR). But the application of SIMABAR in Unswagati still occurs some problems with the many complaints of prospective new students regarding the use of SIMABAR. The study aims at analyzing and explained the influence of user competence to user satisfaction new student admission information system in the University of Swadaya Gunung Jati. Total populations of this study were 2185 first-year students with a total sample of 338 . The sampling technique using stratified proportional random sampling. The analytical method used SEM (Structural Equation Modeling). The results showed that user competence significantly influenced user satisfaction new student admission information system. The better the perception of the quality system, the quality of information, the quality of service, and user competence it will further increase user satisfaction.
\end{abstract}

Keywords- user competence, user satisfaction, student admission

\section{INTRODUCTION}

With the increasing number of State University (PTN) entry points opened, prospective students prefer to enter State Universities (PTN) even with a much more expensive cost, so that Private Universities will only get remnants of prospective students who did not pass the selection at PTN. Coupled with the many assumptions of prospective student parents that PTN is far better than PTS, the more prospective students who prefer to enter PTN than choose to enter PTS. The problem of the decline in New Student Admissions (PMB) was also experienced by Swadaya Gunung Jati University
(UNSWAGATI), where PMB in UNSWAGATI from the last few years continued to decline.

UNSWAGATI develops an information system for New Student Admissions (PMB) is a New Student Admissions Management Information System (SIMABAR) which is used to facilitate prospective students to register online, test online and see graduation results online, and to facilitate officers or committee of UNSWAGATI PMB obtain detailed and valid data and make reports online and in real time so as to facilitate the leadership of UNSWAGATI to make decisions. Although it has utilized the information system in the admission of new students but not necessarily the acceptance of new students at UNSWAGATI increases because there are many factors that influence prospective students choosing to enroll in UNSWAGATI, one of which is user satisfaction, in this case the satisfaction of prospective students using SIMABAR. Reference [1] stated Information system was developed to support the business activities at all levels of the organization, so that the system information can be received and used by all employees in the organization. Reference [2] stated user satisfaction is the ultimate goal of a successful information system. Reference [3] stated In an organization, the amount of information that must be given to each manager depends on the level of the manager's position in the organization because of the higher quality of information produced an information system, will further improve user satisfaction. The factor of user satisfaction on the use of SIMABAR can be seen from the high complaints of prospective students of SIMABAR users about the difficulty of using the application.

Reference [4] stated specifically satisfaction of users defined as " .... the extent to the which users believe that the information system avaible to them meets Reviews their information requirement. Reference [5] stated definition of user satisfaction is" ... The exted to the which an individual 's attitude influences the gap between expectations and the perceived performance of the system ". Reference [6] stated 
" and users satisfaction is an individual 's attitude toward the use of computers , spanning all required computer - related activities or Necessary to Accomplish one 's job. For measure user satisfaction it is quite difficult because the interests of the various parties of the users of information systems are diverse. Many researchers do research to find the most appropriate measure to determine the dimensions of user satisfaction. Reference [7] stated the information system is a harmonious integration of the various components supporting broadly grouped into the organization, management and technology. Reference [8] stated that the information system is an integration of human, hardware, software, databases and networks. The main function of an information system is processing the data into information. Information is basically a resource as well as plant and equipment. Accounting as an information system to identify, collect, and communicating economic information about a business entity to a variety of people. Reference [9] stated the system includes external users (customers, suppliers, partners, and employees) and internal users (clerical and service workers, technical and professional staff, supervisors, middle managers and executive managers ).

Reference [10] stated competence is a level of performance that demonstrate the effective application of knowledge, skills and management. Users of enterprise information system is a resource that can provide a real contribution in achieving strategic objectives and achieve competitive advantage, this applies when the user can actively participate in the development and practice of end-user computing[11]. Reference [12] stated More in-depth explanation of competence have been raised by psychologists. , the competence is divided into two main categories, namely the threshold competencies and differentiating competencies. Threshold competencies include skills and knowledge, while differentiating competencies include social role or the professed values, self- image, character and motive. Inside the company, the employee is a resource and as an end user of a system. Based on the definition and the dimensions or characteristics of user competency information systems mentioned above, the dimensions used to measure the competence of users of information systems in this study refers to the dimensions or characteristics[13], are :

1 ) Knowledge ( knowledge ).

2 ) Skills ( skills ).

As an indicator of each manager's competence characteristics are:

1) Knowledge ( knowledge ), consisting of :

(a) formal education [11]

(b) Have experience [14]

2) Skills ( skills ), consisting of :

(a) Has the ability to understand the specific assignment [15] .

(b) Has the ability to complete certain assignments

(c) Following training on an ongoing basis.

User competence can be a factor that influences SIMABAR user satisfaction. competency is the "ability (ability) or capacity of a person to do various tasks in a job, where this ability is determined by 2 (two) factors namely intellectual ability and physical ability[16]. Main competencies usually consist of a combination of technical skills and skills application. Information system users are resources that can make a real contribution in achieving strategic goals and achieving competitive advantage, this applies if users can actively participate in the development and practice of end-user computing[3]. The competence of SIMABAR users themselves will have an impact on the user's own satisfaction and the acceptance of new students unswagati. Where many prospective students complain that the registration of new students in Unswagati is complicated and complicated, this might happen because of the limited knowledge and skills of prospective students. But if the prospective student has knowledge and is familiar with the use of information technology, this perception might be different.

Reference $[17,18]$ stated demonstrated the competence to influence the quality of accounting information systems. Reference [19] stated demonstrate personal competence affect the quality of accounting information systems but not in all areas of the organization. demonstrate competence affect the quality of the SIA, competence users can improve the quality of SIA. Reference [20] stated demonstrated the ability of users affect the quality of SIA. From data analysis, internal accountants stated competencies have a positive effect on the quality of financial reporting[21]. Reference [22] stated demonstrated the competencies users literally have an impact on the quality of management information systems. Reference [23] stated demonstrated the competence user indirectly has an influence on the satisfaction of information system users.

The formulation of the problem in this study is how the influence of user competence on user satisfaction in the implementation of SIMABAR in UNSWAGATI directly.

The main objective of the research is to find out how far the influence of user competence on user satisfaction in SIMABAR Implementation at Swadaya Gunung Jati University.

\section{Hypothesis}

(1) There is an influence between user competence and user satisfaction Information System Information System for New Student Admissions both partially.

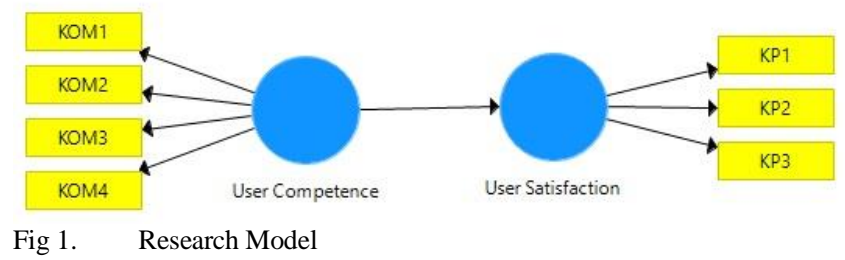

\section{METHOD}

The method in this study uses descriptive verification, descriptive method is a method of researching status, groups of people, an object, a system of thought or a class of events in the present. The unit of analysis is the first year students who have used the new student admission system and is carried out using slovin methods with a sample total of 338 respondents from 728 respondents. Data analysis is done by 
testing the validity and reliability tests and using Smart PLS 3.0

\section{RESULTS AND DISCUSSION}

Partial Least Squares (PLS) was used to analyze the data. The results of the PLS analysis are presented in the following figure.

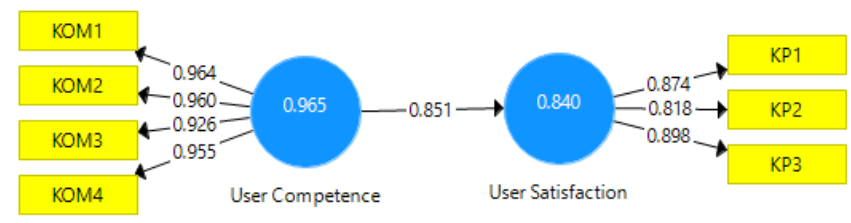

Fig 2. Analysis Model

\section{Measurement Model}

There are three criteria in the use of data analysis technique with SmartPLS to assess the outer model, Convergent Validity, Discriminant Validity and Composite Reliability. An indicator is valid if the loading factor of convergent validity has a value of 0.5 to 0.6 can still be maintained for a model that is still under development[24]. The results in Table 1 show that the items for the independent variables converge on three constructs as originally designed.

TABLE I FACTOR ANALYSIS RESULT

\begin{tabular}{|l|r|r|} 
& \multicolumn{1}{|c|}{$\begin{array}{c}\text { User } \\
\text { Competence }\end{array}$} & $\begin{array}{c}\text { User } \\
\text { Satisfaction }\end{array}$ \\
\hline KOM1 & 0,964 & \\
\hline KOM2 & 0,96 & \\
\hline KOM3 & 0,926 & \\
\hline KOM4 & 0,955 & \\
\hline KP1 & & 0,874 \\
\hline KP2 & & 0,818 \\
\hline KP3 & & 0,898 \\
\hline
\end{tabular}

Based on Table 1 by looking at the convergent validity of each constructor indicator has a loading factor value greater than 0.60 so that it fulfills the validity requirement. Furthermore, reflective indicators also need to be tested for discriminant validity with cross loading. Discriminant validity is done to ensure that each concept of each latent variable is different from other variables. The model has good discriminant validity if each loading value of each indicator of a latent variable has the largest loading value with other loading values against other latent variables.

\begin{tabular}{|c|r|r|}
\multicolumn{1}{c|}{ TABLE II } & \multicolumn{1}{c|}{ CROSS LOADING } \\
& $\begin{array}{c}\text { User } \\
\text { Competence }\end{array}$ & $\begin{array}{c}\text { User } \\
\text { Satisfaction }\end{array}$ \\
\hline KOM1 & 0,964 & 0,827 \\
\hline KOM2 & 0,960 & 0,768 \\
\hline KOM3 & 0,926 & 0,725 \\
\hline KOM4 & 0,955 & 0,898 \\
\hline KP1 & 0,603 & 0,874 \\
\hline KP2 & 0,501 & 0,818 \\
\hline KP3 & 0,955 & 0,898 \\
\hline
\end{tabular}

An indicator is valid if it has the highest loading factor to the intended construct compared to the loading factor to another construct. Table 2 above shows that the loading factor for the User Competency indicator (KOM 1 to KOM 4) has a loading factor to the construct of User Competency higher than that of other constructs. Thus, the latent construct predicts that the indicators on their blocks are better than the indicators in the other blocks.

Another method to see discriminant validity is to see the value of the square root of average variance extracted (AVE). The recommended value is above 0.5. Here are the AVE values in this study:

\begin{tabular}{|c|c|}
\hline \multicolumn{1}{|c|}{ TABLE III } & AVERAGE VARIANCE EXTRACTED \\
& $\begin{array}{r}\text { Average Variance Extracted } \\
\text { (AVE) }\end{array}$ \\
\hline er Competence & $\mathbf{0 , 9 0 5}$ \\
\hline er Satisfaction & $\mathbf{0 , 7 4 7}$ \\
\hline
\end{tabular}

Table 3 above gives AVE values above 0.5 for all constructs contained in the research model. Based on the above description, the size of cross loadings and AVE values have met the requirements, so it can be concluded that the requirements of discriminant validity have been fulfilled.

Reliability testing is done by looking at the composite reliability value of the indicator block that measures the construct. Reliability testing can also be strengthened by Cronbach's Alpha. The results of composite reliability will show a satisfactory value if it is above 0.7 . Here is the value of composite reliability and Cronbach's alpha on the output:

\begin{tabular}{|c|c|c|}
\hline \multicolumn{1}{c|}{ TABLE IV } & \multicolumn{1}{c|}{ COMPOSITE RELIABILIY } \\
\hline & $\begin{array}{c}\text { Cronbach's } \\
\text { Alpha }\end{array}$ & $\begin{array}{c}\text { Composite } \\
\text { Reliability }\end{array}$ \\
\hline User Competence & $\mathbf{0 , 9 6 5}$ & $\mathbf{0 , 9 7 5}$ \\
\hline User Satisfaction & $\mathbf{0 , 8 4 0}$ & $\mathbf{0 , 8 9 8}$ \\
\hline
\end{tabular}

Based on Table 4 above shows that the composite reliability value for all constructs is above 0.7 which shows that all constructs in the estimated model meet the composite reliability criteria. From the results of the table above, we can see the composite reliability value and Cronbach's Alpha value generated the construct is very good that is above 0.7 so it can be concluded that all construct indicators are reliable or in other words all manifest variables of latent variables are proven to have accuracy, consistency and accuracy of instruments in measuring constructs properly.

\section{Structural Model}

A bootstrapping resampling method was used to assess the structural model. The R2 values in the model is 0.724 . Additionally, all paths are statistically significant at the 0.05 level and are in the expected direction. Therefore, the proposed model is considered to have good predictive power. The path coefficient of each hypothesized relationship and its statistical significance was examined to determine the support for the hypothesis. The path coefficient between user competence and user satisfaction was $0.851 \quad(\mathrm{t}=85.747$, pb.000). The PLS structural model results are shown in Figure 3 . 


\begin{tabular}{|c|c|c|c|}
\hline \multicolumn{1}{|c|}{ TABLE V } & \multicolumn{3}{c|}{ PATH COEFFICIENTS } \\
\hline & $\begin{array}{c}\text { Original } \\
\text { Sample } \\
(\mathbf{O})\end{array}$ & $\begin{array}{c}\text { T } \\
\text { Statistics } \\
(\mid \mathbf{O} / \text { S TDE } \\
\text { V] })\end{array}$ & P Values \\
\hline $\begin{array}{c}\text { User Competence -> } \\
\text { User Satisfaction }\end{array}$ & 0,851 & 85,747 & \\
\hline
\end{tabular}

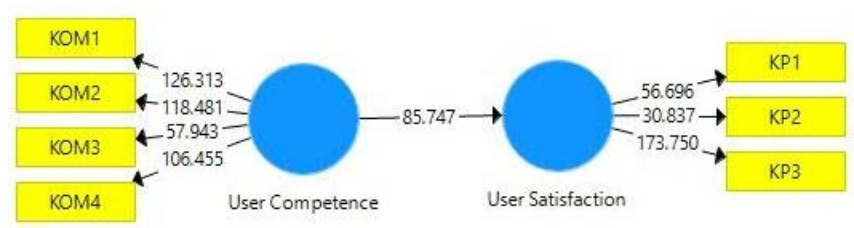

Fig 3. Bootstrapping Model Results

\section{CONCLUSION}

Based on the results of statistical calculations, it can be concluded that the competence of information users has a positive and significant effect on the construct of user satisfaction directly. This shows that an information system that has high user competence tends to have high user satisfaction.

\section{REFERENCES}

[1] Laudon, K.C. \& Laudon, J.P. Management Information Systems. 7th Edition. New Jersey: Prentice-Hall. Inc, 2002

[2] Kaur, B. P., \& Aggrawal, H. "Exploration of Success Factors of Information System". International Journal of Computer Science Issues, (2013), 226-235.

[3] Mcleod, Raymond. Management Information Systems / 10th ed. Upper Saddle River : Pearson Education, 2007

[4] Ives, et al., "The measurement of user information satisfaction," Communications of the ACM, vol. 26, no. 10 (1983), pp. 785-793

[5] Ong, Chong-Shyong., et.al. "The Meansurement of User satisfaction With Question Answering Systems", Information \& Management. Volume 46 (2009). Pp 397-403.

[6] Rainer, R Kelly \& Harrison, Allison W. Introduktion to Information System: Supporting and Transforming Business. 8th Edition. McGrawHill Internasional 1998

[7] Laudon Kenneth C \& Jane P. Laudon. Management Information Systems : New Approaches to Organization \& Technology, International Edition, Prentice Hall, New Jersey, 2005

[8] O'Brien , James A. \& George M. Marakas. Management Information Systems: Managing Information Technology In The Bussiness Enterprise 15th Edition. NY: McGraw-Hill, 2008

[9] Bentley, Lonnie D \& White, Jeffrey L. System Analysis and Design for the Global Enterprise. McGaw-Hill New York, 2007
[10] Funk, Michelle. "Human Resources and Training In mental Health". Mental Healty Policy Information: WHO Library Cotaloguing_in Publication Data, (2005)

[11] McLeod, R. \& Schell, G. Sistem Informasi Akuntansi manajemen.Terjemahan Ali akbar Yulianto dan Afia R.Fitriani.Edisi Kesepuluh. Jakarta: salemba Empat, 2009

[12] Romney, Marshal B. \& Steinbart, Paul John. Accounting Information Systems, Eleventh Edition: New Jersey: Pearson-PrenticeHall, 2009

[13] Spencer, Lyle M. \& Spencer, Signe M. Completence Work Models For Superior Perfrmance Wiley. Canada, 1993

[14] Zikmund, Wiliam G. babin, Barry J. Carr, Jon C \& Griffin, Mitch. Business Reasearch Method, $8^{\text {th }}$ Edition. Sount_South_western Cengage Learning, 2010

[15] Daft, Ricard L. Era baru manajement. Edisi kesembilan Jakarta: salemba Empat, 2010

[16] Robbins, S. Perilaku Organisasi, Edisi Kesepuluh, Penerbit: Indeks, 2006. hal. 585

[17] Nunung Nurhayati, Sri Mulyani. "User Participation On System Development, User Competence and Top Management Commitment and Their effect on The Success of The Implementtaion of Accounting Information System" (Empirical Study in Islamic Bank in Bandung), European Journal of Business and Innovation Research, Vol. 3e Issue No. 2, (2015), 55-68

[18] Deni Iskandar. "Analysis Of Factors Affecting The Success Of The Application Of Accounting Information System", International Journal Of Scientific \& Technology Research Volume 4, Issue 02, Febuary (2015), 155-162

[19] Fadli Moh. Saleh, "Critical success factors and data quality in accounting information systems in Indonesian cooperative enterprises : An empirical". Interdisiplinary Journal Of Contemporay Research in Business , July (2013), 321-338

[20] Meiryani Jun Shien.” Influence of User Ability and Top Management Support on The Quality of Accounting Information System and Its Impact on The Quality Accounting Information". International Journal of Recent Advances in Multidisciplinary Research Vol. 02, Issue 03, pp.0277-0283, March, (2015), 277-283

[21] Hari Setiyawati, The Effect of Internal accountants'Competence, Managers' Commitment to Organizations and the Implementationof the Internal Control system on the Quality of Financial Reporting. International Journal of Business and Management Invention, Volume 2 Issue 11 November (2013), 19-27

[22] Susilawati, Christine Dwi Karya. "How Competence User Impact The Quality Management Information System". 2 nd International Conferences on Information Technology and Business (ICITB) \| October 15th, (2016), 17-23

[23] Hartati, Lesi., \& Zarkasyi, W. "Effect of Competence User Information System, TheQquality of Accounting Information Systems Management and Implications Insatisfaction User Information System (State Owner in Sumatera Selatan)". European Journal of Accounting, Auditing and Finance Research, 3(2), (2015), 35-60

[24] Ghozali, I. Structural Equation Modeling, Metode Alternatif dengan Partial Least Square (PLS), Semarang: Badan Penerbit Universitas Diponegoro, 2014. 